\title{
LEVEL OF INQUIRY PEMBELAJARAN FISIKA: PENGARUHNYA TERHADAP KEMAMPUAN KOGNITIF DITINJAU DARI SIKAPILMIAH SISWA
}

\author{
Sarwanto \\ Program Studi Pendidikan Fisika, Fakultas Keguruan dan Ilmu Pendidikan, Universitas Sebelas Maret, Jl. Ir. Sutami \\ No.36A, Jebres, Surakarta, Indonesia 57126 \\ Email : sarwanto@fkip.uns.ac.id
}

Diajukan: 28 Juli 2020; Diterima: 29 September 2020; Diterbitkan: 31 Oktober 2020

\begin{abstract}
Abstrak: Penelitian ini bertujuan menganalisis: (1) pengaruh level of inquiry (LoI) terhadap kemampuan kognitif; (2) pengaruh sikap ilmiah terhadap kemampuan kognitif, (3) dampak pembelajaran LoI terhadap sikap ilmiah siswa. Pembelajaran LoI dari dibatasi pada inquiry lesson dan guided inquiry lesson. Penelitian ini menggunakan metode kuasi eksperimen. Populasi penelitian ini adalah siswa kelas X salah satu SMA Negeri di Kabupaten Sukoharjo. Sampel dipilih dengan teknik cluster random sampling. Teknik pengumpulan data menggunakan observasi, tes, dan dokumen; analisis data menggunakan uji anova. Hasil penelitian disimpulkan: (1) kemampuan kognitif antara siswa yang diberi pembelajaran guided inquiry lab lebih baik daripada inquiry lesson $\left(\mathrm{F}_{\mathrm{obs}}=4,12>\right.$ $\left.\mathrm{F}_{\alpha}=3,97\right)$, (2) kemampuan kognitif siswa yang memiliki sikap ilmiah tinggi lebih tinggi sikap ilmiah rendah $\left(\mathrm{F}_{\mathrm{obs}}=5,03>\mathrm{F}_{\alpha}=3,97\right)$, (3) tidak ada interaksi pengaruh antara penggunaan pembelajaran inquiry lesson dan guided inquiry lab dengan kategori sikap ilmiah tinggi dan rendah terhadap kemampuan kognitif siswa $\left(\mathrm{F}_{\mathrm{obs}}=0.33>\right.$ $\left.\mathrm{F}_{\alpha}=3,97\right)$.
\end{abstract}

Kata kunci: inquiry lesson, guided inquiry lab, sikap ilmiah, kemampuan kognitif.

\begin{abstract}
This study aims to analyze: (1) the effect of level of inquiry (LoI) on cognitive abilities; (2) the influence of scientific attitudes on cognitive abilities, (3) the impact of LoI learning on students' scientific attitudes. LoI learning is limited to inquiry lessons and guided inquiry lessons. This study uses a quasi-experimental method. The population of this study were students of class X one of the public high schools in Sukoharjo Regency. The sample was selected by cluster random sampling technique. Data collection techniques using observations, tests, and documents; data analysis using ANOVA test. The results of the study concluded: (1) the cognitive abilities of students who were given guided inquiry lab learning were better than the inquiry lesson ( $F o b s=4.12>F \alpha=3.97$ ), (2) the cognitive abilities of students who had high scientific attitudes had higher attitudes. low scientific knowledge (Fobs=5.03 $>F \alpha=3.97$ ), (3) there is no interaction effect between the use of inquiry lesson and guided inquiry lab learning with high and low scientific attitude categories on students' cognitive abilities (Fobs=0.33 > $F \alpha=3.97)$.
\end{abstract}

Keywords: inquiry lesson, guided inquiry lab, scientific attitude, cognitive ability.

\section{Pendahuluan}

Inkuiri atau penyelidikan merupakan salah satu model pembelajaran yang menuntut siswa berperan aktif mengembangkan pengetahuan dan pemahamannya mengenai ide ilmiah layaknya seorang ilmuwan yang mempelajari alam (NRC, 1996). Inkuiri dapat dapat disusun menjadi enam level berdasarkan locus of control dan intellectual sophistication, antara lain: discovery learning, interactive demonstration, inquiry lesson, inquiry lab, real-world application, dan hypothetical inquiry (Wenning, 2005). Hal tersebut diurutkan mulai dari yang pembelajaran yang berpusat pada guru hingga yang berpusat terhadap siswa siswa, serta dari kebutuhan tingkat intelektual yang rendah hingga tinggi.

Inquiry lesson merupakan level ketiga dari enam level inquiry. Menurut Wenning (2005) inquiry lesson sangat mirip dengan demonstrasi interaktif akan tetapi keduanya memiliki perbedaan yang mendasar yaitu inquiry lesson memiliki tingkat kesulitan yang lebih tinggi sehingga memiliki bentuk eksplorasi yang lebih kompleks.

Level selanjutnya setelah inquiry lesson yaitu inquiry lab. Inquiry lab terbagi menjadi guided inquiry lab, bounded inquiry lab, dan 
free inquiry lab. Guided inquiry lab menjadi tahap awal dalam inquiry lab, karena untuk dapat menyelenggarakan tahap inquiry lab yang lebih tinggi, siswa terlebih dahulu harus memiliki pengalaman dalam pembelajaran guided inquiry lab (Wenning, 2005). Pada level guided inquiry lab, guru mengawali kegiatan dengan diskusi guna menyampaikan tujuan pembelajaran serta menentukan variabelvariabel yang hendak diuji. Selanjutnya siswa mencari tahu hubungan antar variabel dengan eksperimen yang juga didesain sendiri oleh siswa.

Nay dan Crocker (1970) menyebutkan bahwa terdapat seperangkat sikap yang mendasari kompetensi dan keberhasilan dalam memperoleh pengetahuan. Sikap-sikap tersebut disebut dengan sikap ilmiah. Beberapa komponen dalam sikap ilmiah antara lain rasa ingin tahu (Pitafi dan Farooq, 2012), cermat sebelum mengambil keputusan (Kozlow dan Nay, 1976), jujur (Pitafi dan Farooq, 2012), objektif (Lacap, 2015), dan berfikiran terbuka (Kozlow dan Nay, 1976). Sikap ilmiah erat kaitannya dengan pembelajaran inkuiri, karena dalam prosesnya sikap-sikap tersebut turut dilibatkan. Misalnya, pada tahap observasi siswa yang memiliki rasa ingin tahu akan banyak mengajukan pertanyaan, karena rasa ingin tahu menjadi faktor yang membangkitkan kemauan untuk mengeksplorasi sesuatu (Pitafi dan Farooq, 2012). Pada saat melakukan eksperimen, siswa yang jujur memiliki kesadaran untuk menuliskan hasil yang sebenarnya (Pitafi dan Farooq, 2012). Siswa yang objektif akan mengesampingkan segala pengaruh dari dalam dirinya dan percaya dengan hal yang diamati (Lacap, 2015). Siswa yang memiliki sikap cermat sebelum mengambil keputusan akan mengumpulkan data sebanyak-banyaknya sebelum menyimpulkan (Pitafi dan Farooq, 2012). Kemudian, pada saat berdiskusi untuk menyimpulkan, siswa yang berfikiran terbuka mampu menerima pendapat orang lain meskipun pendapat tersebut berbeda dengan dirinya (Lacap, 2015).

Wenning (2005) mengungkapkan sebuah teori tentang Levels of Inquiry (LoI), yaitu hieraki inkuiri yang disusun berdasarkan intellectual sophistication (pengalaman intelektual) dan locus of control (pihak pengontrol). Terdapat enam level dalam levels of inquiry, yaitu: inquiry lesson, inquiry lab, real-world application, dan hypothetical inquiry (Wenning, 2005). Tabel 1 menunjukkan tabel hierarki levels of inquiry.

Inquiry lesson menjadi jembatan penghubung antara interactive demonstration dengan inquiry lab. Perbedaan yang mendasar dengan interactive demonstration yaitu pada inquiry lesson lebih meningkatkan tingkat kesulitan menjadi bentuk eksperimen yang lebih kompleks sehingga siswa akan memiliki kesadaran dalam proses kognitifnya sehingga mereka mampu merancang kegiatan belajar selanjutnya dan memantau hasil kerja mereka sendiri (Wenning, 2005).

Guided inquiry lab merupakan transisi dari inquiry lesson ke tahap yang yang lebih tinggi lagi, tetapi bukan transisi sepenuhnya. Guru mengawali kegiatan dengan diskusi atau aktivitas pre lab. Guru membimbing siswa untuk menyebutkan variabel-variabel yang berpengaruh. Siswa mulai mendesain dan melakukan eksperimen untuk memperoleh data. Setelah itu masing-masing kelompok menyampaikan hasil penemuannya untuk kemudian diperoleh kesimpulan (Wenning, 2005). Pada level ini siswa dapat lebih mandiri dalam mengembangkan dan mendesain rencana percobaan serta mengumpulkan data. Selain itu, siswa juga dituntut untuk mampu menganalisis data dengan menggunakan grafik.

Amien (1987) menyebutkan bahwa dalam mempelajari fenomena alam melalui observasi, eksperimen dan analisis, terdapat seperangkat yang diterapkan, antara lain: hasrat ingin tahu, kerendahan hati, jujur, objektif, kemauan untuk mempertimbangkan data baru, pendekatan positif terhadap kegagalan, determinasi, sikap keterbukaan, ketelitian, dsb. Sikap-sikap tersebut disebut dengan sikap ilmiah.

Mukhopadhyay (2014) menambahkan bahwa sikap ilmiah menjadi bagian penting dalam proses pembelajaran. Hal tersebut dikarenakan sikap ilmiah dapat mendukung tumbuhnya pikiran yang penuh tanya dan semangat untuk melakukan penyelidikan terhadap suatu fenomena. Dengan demikian pembelajaran tidak sekedar transfer atau dengan mudah menerima suatu pengetahuan saja, tetapi ada usaha keras untuk mendapatkan pengetahuan. 
Penelitian ini bertujuan untuk menganalisis: (1) pengaruh level of inquiry terhadap kemampuan kognitif; (2) pengaruh sikap ilmiah terhadap kemampuan kognitif, (3) dampak pembelajaran level of inquiry terhadap sikap ilmiah siswa.

\section{Metode}

Metode yang digunakan dalam penelitian ini yaitu kuasi eksperimen dengan desain faktorial $2 \times 2$. Variabel bebas dalam penelitian ini yaitu inquiry lesson dan guided inquiry lab. Variabel moderator dalam penelitian ini yaitu sikap ilmiah siswa, sedangkan variabel terikatnya berupa kemampuan kognitif siswa pada masteri Gerak Melingkar.

Populasi dalam penelitian ini adalah seluruh siswa kelas X MIA semester I SMA Negeri 1 Sukoharjo Tahun Ajaran 2016/2017. Sampel yang terpilih melalui teknik cluster random sampling yaitu kelas X MIA 5 dan X MIA 7 masing-masing terdiri dari 40 siswa. Setelah dilakukan pengundian diperoleh hasil bahwa kelas $\mathrm{X}$ MIA 5 menjadi kelas eksperimen I atau kelas yang diberi pembelajaran inquiry lesson, sedangkan kelas X MIA 7 sebagai kelas eksperimen II atau kelas yang diberi pembelajaran guided inquiry lab. Sebelum diberikan perlakuan, pada kedua sampel dilakukan uji beda rerata melalui uji $\mathrm{t}$ dua ekor untuk mengetahui bahwa kedua sampel yang akan digunakan memiliki keadaan awal yang sama. Sebelum menguji sampel melalui uji-t dua ekor, terlebih dahulu sampel dipastikan sampel berdistribusi normal dan homogen. Hal tersebut dapat diketahui dari uji Liliefors dan uji Bartlett untuk menguji normalitas dan homogenitas sampel.

Hasil perhitungan uji normalitas melalui uji Liliefors diperoleh bahwa kelas eksperimen I memiliki nilai $\mathrm{L}_{\mathrm{obs}}=0,1261$ dan kelas eksperimen II memiliki nilai $\mathrm{L}_{\mathrm{obs}}=0,0870$. Nilai tersebut kurang dari nilai $\mathrm{L}_{\text {tabel }}=0,1401$, sehingga kedua kelas berasal dari populasi yang berdistribusi normal. Sementara berdasarkan uji homogenitas melalui uji Bartlett diperoleh nilai $\chi_{\text {hitung }}^{2}=0,2788$. Nilai tersebut kurang dari nilai $\chi^{2}$ tabel yaitu $\chi_{0.05: 1}^{2}=3,841$. Dengan demikian kedua sampel berasal dari populasi yang homogen.
Setelah kedua prasyarat analisis terpenuhi, selanjutnya kedua sampel diuji beda rerata melalui uji-t dua ekor. Berdasarkan perhitungan uji $\mathrm{t}$ diperoleh nilai $\mathrm{t}=0,19097$. Nilai tersebut kurang dari $t_{\text {tabel }}=1,99125(\alpha=\%$ dan $\mathrm{df}=78$ ). Dengan demikian thitung kurang dari $t_{\text {tabel }}$ yang artinya tidak ada perbedaan kemampuan awal antara kedua sampel.

Dua teknik pengumpulan data yang digunakan dalam penelitian ini yaitu teknik tes dan kajian dokumen. Teknik tes digunakan untuk memperoleh data sikap ilimiah siswa dan kemampuan kognitif siswa setelah melalui proses pembelajaran pada materi Gerak Melingkar. Kajian dokumen dilakukan terhadap beberapa dokumen seperti silabus, buku pelajaran kelas X, daftar absensi kelas X MIA serta daftar nilai ulangan harian yang dimiliki guru Data dianalisis menggunakan analisis variansi dua jalan dengan isi sel tak sama.

\section{Hasil Dan Pembahasan}

Hasil tes kemampuan kognitif pada kedua sampel disajikan dalam Tabel 1 .

\begin{tabular}{cccc}
\multicolumn{2}{c}{ Tabel 1. Data Kemampuan Kognitif Siswa } \\
\hline \multirow{2}{*}{$\begin{array}{c}\text { Level of } \\
\text { inquiry (A) }\end{array}$} & & Tikap Ilmiah (B) \\
\cline { 3 - 4 } & & Tingi & $\begin{array}{c}\text { Rendah } \\
(\mathrm{B} 2)\end{array}$ \\
\hline Inquiry & $\mathrm{N}$ & 21 & 19 \\
Lesson (A1) & Mean & 77,21 & 73,16 \\
& $\mathrm{SD}$ & 12,51 & 13,67 \\
\hline Guided & $\mathrm{N}$ & 22 & 18 \\
Inquiry & Mean & 83,51 & 76,69 \\
Lab(A2) & SD & 7,63 & 8,26 \\
\hline
\end{tabular}

Sebagai prasyarat analisis, telah dilakukan uji normalitas dan homogenitas terhadap nilai siswa. Hasil uji normalitas dengan $\chi^{2}$ bahwa seluruh kelompok berdistribusi normal. Sedangkan hasil uji homogentitas dengan uji Levene menunjukkan bahwa kedua sampel kelas berasal dari populasi yang homogen, baik ditinjau dari Levels of Inquiry, sikap ilmiah, maupun antar sel.

Selanjutnya berdasarkan perhitungan statistik dengan taraf signifikansi $(\alpha) \quad 5 \%$ diperoleh hasil uji hipotesis seperti pada Tabel 2.

\begin{tabular}{|c|c|c|}
\hline Sumber & $\mathrm{F}_{\mathrm{obs}}$ & $\mathrm{F}_{\alpha}$ \\
\hline Levels of Inquiry (A) & 4,12 & 3,97 \\
\hline Sikap Ilmiah (B) & 5,03 & 3,97 \\
\hline Interaksi (AB) & 0,33 & 3,97 \\
\hline
\end{tabular}




\section{Level of Inquiry (LoI)}

Hasil uji anova menunjukkan bahwa ada perbedaan kemampuan kognitif siswa yang diberi pembelajaran dengan inquiry lesson dan guided inquiry lab. Tabel 1 menunjukkan bahwa kemampuan kognitif hasil pembelajaran dengan guided inquiry lab lebih baik dari pada inquiry lesson.

Hierarki inkuiri (Wenning, 2005) mengindikasikan bahwa bimbingan yang diberikan guru pada guided inquiry lab lebih sedikit dari pada inquiry lesson, sehingga keterampilan proses intelektual yang dibutuhkan pada level tersebut juga lebih tinggi. Inquiry lesson merupakan level peralihan dari interactive demonstration menuju inquiry lab, oleh karena itu dalam proses pembelajaran, demonstrasi masih digunakan pada awal pembelajaran sebelum masuk ke bagian eksperimen. Selain itu, dalam proses pembelajaran, guru masih banyak memberikan bimbingan kepada siswa. Berbeda dengan guided inquiry lab, bimbingan yang diberikan kepada siswa lebih sedikit, sehingga porsi siswa untuk mengembangkan kemampuan berfikirnya menjadi lebih besar. Pengalaman yang diperoleh saat melakukan penyelidikan menjadi lebih banyak.

Lingkungan sosial menjadi media bagi siswa untuk berinteraksi dengan yang lain (NRC, 2000). Peran guru pada pembelajaran guided inquiry lab yang lebih sedikit dari pada peran guru pada inquiry lesson mampu memberikan kesempatan siswa untuk saling berinteraksi dan membangun dialog yang lebih banyak dengan teman-teman satu kelompok pada pembelajaran guided inquiry lab lebih banyak dibanding pada pembelajaran inquiry lesson. Pada saat dialog, maka akan tumbuh pengetahuan-pengetahuan baru melalui modifikasi hal-hal yang diketahui sebelumnya atau bahkan siswa mengganti pemahaman lama dengan pemahaman yang baru (Wenning, 2011). Dibandingkan dengan bekerja sendiri, jika siswa bekerja secara kooperatif dalam satu kelompok, maka mereka akan lebih mudah dalam memecahkan masalah kompleks di dalam laboratorium maupun masalah dalam kehidupan sehari-hari. Selain itu melalui kelompok tersebut siswa memiliki kesempatan untuk "berbicara mengenai sains" dengan lebih leluasa, nyaman, bebas bertukar ide tanpa rasa malu atau takut (Wenning, 2011). Selain itu, dengan adanya diskusi dan kerja yang kooperatif dapat menumbuhkan kesadaran bahwa ilmu merupakan hasil kerja dari sekelompok orang. Kejeniusan seorang tidak selalu menjadi jaminan, tetapi keberhasilan dan kemajuan dapat diperoleh dari akumulasi beberapa langkah kecil (Wenning, 2011). Hasil tersebut didukung dengan hasil riset Wenning (2011) yang menyatakan bahwa, ketika bimbingan dari guru memiliki porsi yang lebih sedikit, maka hal tersebut dapat membantu siswa dalam mengembangkan problem solving skill (keterampilan menyelesaikan masalah) sehingga pada saat menghadapi tes, mereka akan lebih mudah dalam menyelesaikan persoalan yang disajikan.

\section{Sikap Ilmiah}

Hasil analisis anova menunjukkan bahwa ada perbedaan kemampuan kognitif antara siswa dengan sikap ilmiah tinggi dan siswa dengan sikap ilmiah rendah $\left(\mathrm{F}_{\mathrm{obs}}=5,03>\right.$ $\left.F_{\alpha}=3,97\right)$ Tabel 1 juga menunjukkan bahwa hasil kemampuan kognitif siswa yang memiliki sikap ilmiah tinggi lebih tinggi dari pada siswa yang memiliki sikap ilmiah rendah. Dalam penelitian ini, dimensi sikap ilmiah yang diujikan antara lain rasa ingin tahu (curiousity), cermat sebelum membuat keputusan (suspend judgement), jujur (honesty), objektif (objectivity), dan berfikiran terbuka (open mindedness).

Rasa ingin tahu merupakan salah satu dimensi sikap ilmiah yang dapat dikatakan sebagi keinginan untuk mengetahui jawaban atas pertanyaan "mengapa" dan "bagaimana" (Lacap, 2015). Rasa ingin tahu menjadi faktor yang dapat membangkitkan seseorang untuk mengeksplorasi sesuatu (Pitafi dan Farooq, 2012). Dengan adanya rasa ingin tahu, maka data input pada sensor yang ada dalam tubuh akan semakin bertambah. Seseorang yang memiliki rasa ingin tahu yang tinggi akan berani bertanya, mencari informasi, berani memulai sesuatu, serta berani untuk melakukan penyelidikan (Pitafi dan Farooq, 2012). Siswa yang memiliki rasa ingin tahu yang tinggi akan lebih semangat dalam mengikuti pelajaran, lebih sering bertanya baik kepada teman maupun guru, mengeksplor alat-alat percobaan yang ada di hadapannya, dan berani melakukan percobaan. Dengan demikian, pengetahuan 
yang diperoleh akan lebih banyak dibandingkan siswa yang rasa ingin tahunya rendah.

$$
\text { Kozlow dan Nay }
$$

mengungkapkan beberapa ciri siswa yang memiliki sikap cermat dalam mengambil keputusan, antara lain menggeneralisasikan sesuatu hanya jika ada bukti yang kuat dan tepat, mengumpulkan bukti sebanyakbanyaknya sebelum mengambil kesimpulan, serta menyadari bahwa kesimpulan yang diambil bersifat tentatif. Siswa yang memiliki sikap cermat dalam mengambil keputusan maka siswa tersebut akan cenderung lebih hatihati dalam mengambil data dan akan menggunakan seluruh data yang diperoleh. Pitafi dan Farooq (2012) menyebutkan bahwa siswa yang memiliki sikap cermat dalam mengambil keputusan akan cenderung tidak akan mengeluarkan opininya terhadap suatu fenomena sebelum ia melakukan penyelidikan terhadap fenomena tersebut. Siswa yang memiliki sikap cermat dalam mengambil keputusan tinggi akan melakukan penyelidikan dengan lebih sungguh-sungguh dan mengumpulkan data sebanyak-banyaknya. Siswa tersebut tidak akan sungkan untuk berkonsultasi dengan guru sebelum mengambil kesimpulan atas penyelidikan yang dilakukan. Oleh karena itu pengetahuan yang diperoleh akan lebih banyak dari pada siswa yang memiliki sikap cermat dalam mengambil keputusan rendah.

Jujur menjadi salah satu dimensi sikap ilmiah yang sangat penting. Hal tersebut erat kaitannya dengan aktivitas siswa selama penyelidikan. Siswa ditantang untuk bisa bersikap jujur terhadap hasil observasinya. Salah satu ciri sikap jujur yang dijelaskan oleh Kozlow dan Nay (1976) yaitu melaporkan hasil observasi meskipun bertentangan dengan hipotesis. Siswa dengan yang memiliki dimensi sikap jujur tinggi maka siswa tersebut akan percaya dengan data yang hasil amatannya meskipun hasil tersebut berbeda dengan hipotesinya. Jujur berarti kesadaran untuk melaporkan hasil observasi yang sesungguhnya (Pitafi dan Farooq, 2012).

Lacap (2015) menyatakan bahwa seorang saintis harus secara kontinyu untuk mengingatkan dirinya agar selalu berusaha bersikap objektif. Objektif berarti terbebas dari segala pengaruh yang berasal dari harga diri atau kebanggaan personal, bias, serta ambisi
(Lacap, 2015). Siswa yang memiliki dimensi sikap objektif maka pada saat pengambilan data eksperimen siswa tersebut akan tetap melaporkan hasil pengamatannya sendiri. Ia tidak akan terpengaruh oleh orang lain.

Open mindedness atau berfikiran terbuka berarti peduli dan mau mendengarkan idea tau opini yang disampaikan orang lain, menerima kritik, dan mau mengubah pemikirannya ketika menemui fakta baru yang bertentangan dengan pemikirannya saat ini (Lacap, 2015). Siswa yang berfikiran terbuka akan lebih mudah menerima hal-hal baru yang bertentangan dengan pengetahuan lamanya. Dalam proses belajar, siswa berusaha untuk membangun pengetahuan baru dengan memodifikasi dan menyuling konsep lama mereka serta menambahkan konsep baru yang ia temui (NRC, 2000). Siswa dengan sikap open mindedness yang tinggi tidak akan bersikap kaku dengan hal-hal yang diketahuinya saat ini, tetapi ia akan bersikap luwes yang berarti mau mendengarkan informasi baru, ide baru, dan mempertimbangkan beberapa kemungkinan dalam menyelidiki sesuatu. Dengan demikian pengetahuan yang dimiliki akan lebih luas dan terus berkembang.

\section{Interaksi pengaruh LoI dan Sikap Ilmiah}

Hasil anava menunjukkan tidak terdapat interaksi antara pembelajaran inquiry lesson dan guided inquiry lab dengan sikap ilmiah terhadap kemampuan kognitif siswa $\left(\mathrm{F}_{\mathrm{obs}}=0,33\right.$ $\left.<\mathrm{F}_{\alpha}=3,97\right)$. Dengan kata lain, penggunaan pembelajaran inquiry lesson maupun guided inquiry lab dan kategori sikap ilmiah memberikan pengaruh masing-masing terhadap kemampuan kognitif siswa. Tabel 1 menunjukkan siswa dengan sikap ilmiah tinggi pada kedua kelas memiliki kemampuan kognitif yang lebih tinggi dari pada siswa yang memiliki sikap ilmiah rendah.

Sikap ilmiah siswa akan memberikan pengaruh yang sama meskipun siswa diberi pembelajaran dengan inquiry lesson maupun guided inquiry lab. Siswa yang memiliki sikap ilmiah tinggi akan memiliki kemampuan kognitif yang lebih tinggi dari pada siswa yang memiliki sikap ilmiah rendah, baik diberi pembelajaran dengan inquiry lesson maupun guided inquiry lab. Sementara itu, pembelajaran dengan guided inquiry lab juga 
memberikan pengaruh yang sama pada siswa yang memiliki sikap ilmiah tinggi maupun rendah. Pembelajaran dengan guided inquiry lab menghasilkan kemampuan kognitif yang lebih baik dibanding dengan pembelajaran dengan inquiry lesson baik untuk siswa yang memiliki sikap ilmiah tinggi maupun rendah. Tidak adanya interaksi antara pembelajaran inquiry lesson dan guided inquiry lab dengan sikap ilmiah terhadap kemampuan kognitif siswa menunjukkan bahwa tidak ada perbedaan efek antara siswa yang diberi pembelajaran dengan inquiry lesson dan guided inquiry lab ditinjau dari sikap ilmiah terhadap kemampuan kognitif siswa.

\section{Kesimpulan}

Berdasarkan hasil penelitian dapat disimpulkan bahwa: (1) ada perbedaan kemampuan kognitif antara siswa yang diberi pembelajaran inquiry lesson dan guided inquiry lab $\left(\mathrm{F}_{\mathrm{obs}}=4,12>\mathrm{F}_{\alpha}=3,97\right)$, (2) ada perbedaan kemampuan kognitif antara yang memiliki sikap ilmiah tinggi dan sikap ilmiah rendah $\left(\mathrm{F}_{\mathrm{obs}}=5,03>\mathrm{F}_{\alpha}=3,97\right)$, (3) tidak ada interaksi pengaruh antara penggunaan pembelajaran inquiry lesson dan guided inquiry lab dengan kategori sikap ilmiah tinggi dan rendah terhadap kemampuan kognitif siswa $\left(\mathrm{F}_{\mathrm{obs}}=0,33\right.$ $\left.>\mathrm{F}_{\alpha}=3,97\right)$.

\section{Daftar Pustaka}

Amien, M. (1987). Mengajarkan Ilmu Pengetahuan Alam (IPA) dengan Menggunakan Metode
Discovery dan Inquiry. Yogyakarta: Departemen Pendidikan dan Kebudayaan Direktorat Jenderal Pendidikan Tinggi Proyek Pengembangan Lembaga Pendidikan Tenaga Kependidikan.

Kozlow, M. J., \& Nay, M. A. (1976). An Approach to Measuring Scientific Attitudes. Science Education, 147-172.

Lacap, M. P. (2015). The Scientific Attitudes of Students Major In Science in the New Teacher Education Curriculum. Asia Pacific Journal of Multidisciplinary Research, 7-15.

Mukhopadhyay, R. (2014). Scientific Attitude Some Psychometric Considerations. Journal Of Humanities And Social Science, 98-100.

National Research Council. (1996). National Science Education Standards. Washington: National Academies Press.

National Research Council . (2000). Inquiry and National Science Education Standards : A Guide for Teaching and Learning. Washington: National Academies Press.

Nay, M. A., \& Crocker, R. K. (1970). Science Teaching and The Affective Attributes of Scientist. Science Education, 59-67.

Pitafi, A. I., \& Farooq, M. (2012). Measurement of Scientific Attitude of Secondary School Students in Pakistan. Academic Research International, 379-392

Wenning, C. J. (2005). Levels of inquiry: Hierarchies of Pedagogical Practices and Inquiry Processes. Journal of Physics Teacher Education Online , 3-12.

Wenning, C. J. (2011). Experimental Inquiry in Introductory Physics Courses. Journal of Physics Teacher Education Online , 2-8. 